\title{
KOMPETENSI PEDAGOGIK GURU BAHASA INDONESIA DALAM IMPLEMENTASI KURIKULUM 2013 DI SMA KABUPATEN MUNA BARAT
}

\author{
Susi $^{1}$, Aris Badara ${ }^{2}$, Muh. Yazid A. R. G ${ }^{3}$ \\ Universitas Halu Oleo
}

Email: $\underline{\text { susispd80@gmail.com }}$, $\underline{\text { arisbadara71@yahoo.co.id }}{ }^{2}, \underline{\text { mgege9917@,gmail.com }}{ }^{3}$

\begin{abstract}
Abstrak: Penelitian ini bertujuan untuk: (1) mengetahui kompetesi pedagogik guru bahasa Indonesia dalam perencanaan pembelajaran pada implementasi Kurikulum 2013 di SMA Kabupaten Muna Barat; (2) untuk mengetahui kompetensi pedagogik guru bahasa Indonesia dalam pelaksanaan pembelajaran pada implementasi Kurikulum 2013 di SMA Kabupaten Muna Barat; (3) untuk mengetahui kompetensi pedagogik guru bahasa Indonesia dalam penilaian pembelajaran pada implementasi Kurikulum 2013 di SMA Kabupaten Muna Barat. Jenis penelitian ini merupakan penelitian kualitatif, yaitu penelitian yang dilakukan dengan tujuan utama untuk menggambarkan atau memaparkan suatu obejek yang diteliti. Selanjutnya data dianalisis menggunakan teknik: (1) Reduksi Data; dan (2) Penyajian Data. Hasil penelitian ini menunjukkan bahwa, Kompetensi Pedagogik Guru Bahasa Indonesia dalam Implementasi Kurikum 2013 di SMA Kabupaten Muna Barat tergolong baik. Sebagai acuan dalam proses mengetahui kompetensi pedagogik guru dalam implementasi Kurikulum 2013 ditentukan oleh: (1) kemampuan menyusun Rencana Pelaksanaan Pembelajaran (RPP); (2) Pelasanaan Pembelajaran; dan (3) Pelaksanaan Penilaian. Pada tahap perencanaan pembelajaran guru menyusun Rencana Pelaksanaan Pembelajaran (RPP) yang kemudian diimplementasikan dalam pelaksanaan pembelajaran dengan menggunakan pendekatan saintifik. Selanjutnya melaksanakan penilaian dengan menggunakan penilaian autentik dalam pembelajaran.
\end{abstract}

Kata Kunci: Implementasi; Kurikulum; Kompetensi; Pembelajaran; Pedagogik 


\section{Pendahuluan}

Dalam pembukaan UUD 1945 dinyatakan bahwa salah satu tujuan dibentuknya negara Republik Indonesia adalah untuk mencerdaskan kehidupan bangsa. Sejalan dengan hal tersebut, maka pendidikan merupakan salah satu instrumen penting untuk mewujudkan kecerdasan bangsa. Pendidikan sendiri merupakan sebuah proses yang dilakukan dengan tujuan membawa anak didik menjadi manusia dewasa, matang dan bertanggung jawab (Suhardjono 1995:95).

Menurut undang-undang sistem pendidikan nasional (SISDIKNAS), pendidikan nasional berfungsi mengembangkan kemampuan dan bentuk watak serta peradaban bangsa yang martabat dalam rangka mencerdaskan kehidupan bangsa, bertujuan untuk mengembangkan potensi peserta didik agar menjadi manusia yang beriman dan bertakwa kepada Tuhan Yang Maha Esa, berakhlak mulia, sehat, berilmu, cakap, kreatif, mandiri dan menjadi warga negara yang demokratis serta bertanggung jawab.

Menurut (Badara dkk, 2018) "Such behavior would be similar to what is aspired by the goal of character education is religious, honest, tolerance, discipline, work hard, creative, independent, democratic, national spirit, loving homeland, appreciating achievements, friendship, loving peace, joy of reading, caring environmental, social care, and responsibility". "Perilaku seperti itu akan terjadi mirip dengan apa yang dicita-citakan oleh tujuan pendidikan karakter adalah agama, jujur, toleransi, disiplin, kerja keras, kreatif, mandiri, demokratis, semangat kebangsaan, penyayang tanah air, menghargai prestasi, persahabatan, cinta damai, suka membaca, peduli lingkungan, kepedulian sosial, dan tanggung jawab.
Dilihat dari pernyataan di atas bahwa pendidikan diharapkan dapat membentuk manusia yang cerdas dalam berbagai apek baik intelektual, sosial, emosional, maupun spiritual, serta memiliki sikap dan perilaku mulia yang berguna bagi kepentingan dirinya dan masyarakat. Sehingga dapat berpengaruh terhadap peningkatan kualitas sumber daya manusia yang dapat menentukan keberhasilan pembangunan bangsa.

Untuk mencapai pendidikan di atas, pemerintah menyadari betapa pentingnya peningkatan kualitas pendidikan sebagai proses peningkatan sumber daya manusia. Berbagai upaya telah dilakukan pemerintah, mulai dari perbaikan kurikulum dan sistem evaluasi, pernbaikan sarana dan prasarana, pengembangan dan pengadaan materi pelajaran serta evaluasi tenaga pendidik pun telah dilakukan. Dari upaya yang dilakukan, perbaikan dan evaluasi tenaga pendidik (guru) dinilai merupakan hal penting dalam proses kualitas pendidikan.

Keberhasilan pelaksanaan Kurikulum 2013 tidak terlepas dari peran tenaga kependidikan khususnya guru. Undang-Undang Nomor 14 tahun 2005 menyatakan bahwa guru adalah pendidik profesional dengan tugas utama mendidik, mengajar, membimbing, mengarahkan, melatih, menilai, dan mengevaluasi peserta didik pada pendidikan anak usia dini jalur formal, pendidikan dasar, dan pendidikan menengah. Selain itu guru adalah pendidik yang menjadi tokoh, panutan, dan indentifikator bagi peserta didik dan lingkungannya. Oleh karena itu, guru harus memiliki standar kualitas tertentu, yang mencakup tanggung jawab, wibawa, mandiri, dan disiplin.

Perlu dipahami bahwa untuk menjadi seorang guru yang profesional harus memiliki beberapa standar kompetensi salah satunya adalah 
kompetensi pedagogik. Hal ini sebagaimana diatur oleh peraturan pemerintah Republik Indonesia No 74 tahun 2008 tentang guru. Kompetensi pedagogik bisa dikatan sebagai ruh dari seorang guru karena kompetensi inilah yang menjadi pembeda dari profesiprofesi lain. Kompetensi pedagogik adalah kemampuan mengelola pembelajaran peserta didik yang meliputi pemahaman terhadap peserta didik, perancangan dan pelaksanaan pembelajaran, evaluasi hasil belajar dan pengembangan peserta didik untuk mengaktualisasikan berbagai potensi yang dimilikinya (Standar Nasional pasal 28 ayat 3 butir a).

Tujuan tersebut bisa tercapai bila guru memiliki kompetensi yang komplit. Kompetensi guru meliputi kompetensi pedagogik, kompetensi kepribadian, kompetensi sosial, dan kompetensi profesional yang diperoleh melalui pendidikan profesi. Seorang guru profesional harus memiliki keempat elemen tersebut (Kurniasih, 2016:8). Dalam perspektif kebijakan pendidikan terkait dengan kompetensi guru tersebut bersifat menyeluruh dan merupakan satu kesatuan yang satu sama lain saling berhubungan dan saling mendukung. Kompetensi pedagogik merupakan bagian yang tak terpisahkan dari empat kompetensi utama yang harus dimiliki seorang guru. Keempat kompetensi tersebut terintegrasi dalam kinerja guru saat melaksanakan profesinya.

Permasalahan pendidikan yang muncul membuat Kemendikbud menilai perlu dikembangkan kurikulum baru yaitu Kurikulum 2013. Pengembangan kurikulum 2013 dilakukan karena adanya tantangan internal maupun tantangan eksternal. Tantangan internal terkait tuntutan pendidikan yang mengacu pada 8 Standar Nasional Pendidikan dan faktor perkembangan penduduk Indonesia. Tantangan eksternal berkaitan dengan tantangan masa depan, kompetensi yang diperlukan di masa depan, persepsi masyarakat, perkembangan pengetahuan dan pedagogik, serta berbagai fenomena negatif yang mengemuka (Kemendikbud, 2014:6).

Dari hasil observasi yang peneliti lakukan sebelumnya, dalam pelaksanaan kurikulum 2013 di SMA Kabupaten Muna Barat masih memiliki kendala dalam proses evaluasinya. Beberapa kendala yang ada antara lain yaitu pada tahap persiapan, pelaksanaan, dan evaluasi Kurikulum 2013. Pada tahap persiapan, masalah yang dihadapi adalah belum semua guru menguasai teknologi informasi seperti penguasaan komputer dan jaringan internet yang kurang memadai sehingga menghambat kelancaran dalam pelaksanaan pembelajaran RPP, pengolahan nilai, dan menggunakan media pembelajaran multimedia.

\begin{tabular}{lll}
\multicolumn{2}{c}{ Kemudian pada } & tahap \\
pelaksanaan atau penerapan & dalah \\
pelaksanaan pembelajaran tidak & dapat
\end{tabular} tuntas dalam satu kali pertemuan atau satu hari karena banyak kegiatan yang harus dilakukan guru dan siswa, dalam pembelajaran guru melakukan penilaian autentik untuk setiap aspek, dan siswa menyelesaikan kegiatan pembelajaran yang padat.. Jam pelajaran siswa yang lebih padat dalam setiap minggu. Kemudian guru kesulitan dalam mengakomodasikan pendekatan saintifik dengan 5 langkah (mengamati, menanya, mencoba, menalar, dan mengkomunikasikan) pada kegiatan pembelajaran. Kesulitan ini ditambah ketika anak kurang aktif, padahal tuntutan dengan pendekatan saintifik ini, siswa harus aktif.

Selanjutnya masalah yang dihadapi dalam tahap evaluasi/penilaian yang dihadapi guru antara lain sistem penilaian autentik belum bisa dilakukan secara maksimal oleh guru mengingat 
jumlah siswa dan banyaknya unsur penilaian. Termasuk didalamnya dalam mengatur daftar nilai, buku laporan hasil belajar (raport). Ini juga merupakan dampak yang dirasakan para pendidik dan peserta didik dengan diberlakunya Kurikulum 2013 di SMA Kabupaten Muna Barat.

Beberapa penelitian yang pernah dilakukan, seperti penelitian Setyawan Pujiono (2014) menyinpulkan bahwa untuk meningkatkan kesiapan implementasi Kurikulum 2013 dilakukan dengan memperbanyak sosialisasi, memperkaya materi pendukung, dan pelatihan penyusunan rencana program pembelajaran (RPP). Kemudian penelitian Hidayah, dkk., (2015) menyimpulkan bahwa skor rata-rata hasil analisis angket aspek sikap guru terhadap implementasi kurikulum 2013 yang terbagi menjadi 26 butir pernyataan yaitu 3,8 dengan kategori baik. Sikap guru terhadap implementasi kurikulum 2013 sebagian besar memberi respon yang positif, tetapi di sisi lain faktor kesiapan guru terhadap implementasi kurikulum 2013 masih perlu ditingkatkan.

Berdasarkan uraian di atas, maka peneliti tertarik melakukan penelitian dengan judul "Kompetensi Pedagogik Guru Bahasa Indonesia dalam Implementasi Kurikulum 2013 di SMA Kabupaten Muna Barat".

\section{Fungsi Kurikulum}

Hamalik (1990:87) menyatakan bahwa terdapat tiga peranan kurikulum yaitu: (a) peranan konservatif menekankan bahwa kurikulum itu dapat dijadikan sebagai sarana untuk mentrasmisikan atau mewariskan nilainilai budaya masa lalu yang dianggap masih relevan dengan masa kini pada generasi muda, dalam hal ini para peserta didik di sekolah dasar; (b) peranan kreaktif yang menekankan bahwa kurikulum harus mampu mengembangkan sesuatu yang baru sesuai dengan perkembangan yang terjadi dan kebutuhan-kebutuhan masyarakat pada masa sekarang dan masa yang akan datang; dan (c) peranan kritis dan evaluatif, dilatarbelakangi adanya kenyataan bahwa nilai-nilai dan budaya yang hidup dalam masyarakat senantiasa mangalami perubahan sehingga pewarisan nilai-nilai dan budaya masa lalu kepada peserta didik perlu disesuaikan dengan kondisi yang terjadi pada masa sekarang.

\section{Kompetensi Guru}

Kompetensi guru merupakan peleburan dari pengetahuan (daya pikir), sikap (daya kalbu), dan keterampilan (daya pisik) yang diwujudkan dalam bentuk perbuatan. Dengan kata lain, kompetensi merupakan perpaduan dari penguasaan pengetahuan, keterampilan, nilai, dan sikap yang direfleksikan dalam kebiasaan berpikir dan bertindak dalam melaksanakan tugas/pekerjaannya. Dapat juga dikatakan bahwa kompetensi merupakan gabungan dari kemampuan, pengetahuan, kecakapan, sikap, sifat, pemahaman, apresiasi dan harapan yang mendasari karakteristik seseorang untuk berunjuk kerja dalam menjalankan tugas atau pekerjaan guna mencapai standar kualitas dalam pekerjaan nyata. Jadi, kompetensi merupakan seperangkat pengetahuan, keterampilan, dan perilaku yang harus dimiliki, dihayati, dan dikuasai oleh guru untuk dapat melaksanakan tugas-tugas profesionalnya, Syaiful Sagala (2009: 23).

\section{Kompetensi Pedagogik}

Undang-Undang Nomor 14 Tahun 2005 tentang Guru dan Dosen pasal 10 menyatakan bahwa kompetensi guru meliputi kompetensi pedagogik, kompetensi kepribadian, kompetensi sosial, dan kompetesi profesional yang diperoleh melalui pendidikan profesi. Kompetensi merupakan seperangkat pengetahuan, keterampilan, dan perilaku 
yang harus dimiliki, dihayati, dikuasai, dan diaktualisasikan oleh guru dalam melaksanakan tugas keprofesionalan.

Peraturan Pemerintah RI Nomor 74 Tahun 2008 tentang Guru pasal 4 menyatakan bahwa kompetensi pedagogik merupakan kemampuan guru dalam pengelolaan pembelajaran peserta didik yang sekurang-kurangnya meliputi: (1) pemahaman wawasan atau landasan kependidikan; (2) pemahaman terhadap peserta didik; (3) pengembangan kurikulum atau silabus; (4) perancangan pembelajaran; (5) pelaksanaan pembelajaran yang mendidik dan dialogis; (6) Pemanfaatan teknologi pembelajaran; (7) evaluasi hasil belajar; dan (8) pengembangan peserta didik untuk mengaktualisasikan berbagai potensi yang dimilikinya.

Kurniasih (2016:8) menyatakan bahwa kompetensi pedagogik merupakan kemampuan yang berkaitan dengan pemahaman peserta didik dan mengelola pembelajaran yang mendidik dan dialogis. Kopetensi utama yang harus dimiliki guru agar pembelajaran yang dilakukan efektif dan dinamis adalah kompetensi pedagogik. Guru harus belajar secara maksimal untuk menguasai kompetenasi pedagogik secara teori dan praktik, sehingga perubahan dan kemajuan akan terjadi dengan pesat dan produktif.

Beberapa pendapat para ahli itu maka dapat disimpulkan bahwa kompetensi pedagogik adalah kemampuan guru dalam mengelolah proses pembelajaran peserta didik secara utuh.

\section{Pembelajaran Bahasa Indonesia dalam Kurikulum 2013}

Achmad (2012:10) mengatakan bahasa adalah sistem lambang bunyi yang arbitrer yang dipergunakan oleh para anggota kelompok sosial untuk bekerja sama, berkomunikasi, dan mengidentifikasi diri. Bahasa sebagai simbol yang bermakna terdiri atas satuan- satuan tertentu yang secara fungsional saling berhubungan sebagai suatu sistem bahasa. Dengan bahasa, manusia bekerja sama dalam masyarakat tempat mereka berada, ketika manusia berinteraksi antarindividu yang satu dengan yag lain diperlukan bahasa.

Pateda (dalam A.D., Firman, 2008:7) mengatakan bahasa merupakan saluran untuk menyampaikan semua yang dirasakan, dipikirkan, dan diketahui seseorang kepada orang lain. Bahasa juga memungkinkan manusia dapat bekerja sama dengan orang lain dalam masyarakat. Hal tersebut berkaitan erat dengan hakikat manusia sebagai makhluk sosial yang memerlukan bahasa untuk memenuhi hasratnya.

\section{Pengertian Kurikulum}

Hernawan (2013:1.5) menyatakan bahwa kurikulum menjadi empat dimensi pengertian yang saling berhubungan yaitu: (a) kurikulum sebagai suatu ide/gagasan; (b) kurikulum sebagai suatu rencana tertulis, yang sebernarnya merupakan perwujudan daripada kuririkulum sebagai suatu ide; (c) kurikulum sebagai suatu kegiatan, yang sering pula disebut dengan suatu istilah kurikulum sebagai suatu realita atau implementasi kurikulum, secara teoritis dimensi kurikulum ini adalah pelaksanaan kurikulum sebagai rencana tertulis; dan (d) kurikulum sebagai suatu hasil, yang merupakan konsekuensi dari kurikulum sebagai suatu kegiatan

\section{Implementasi Kurikulum 2013}

Miller mendefenisikan implementasi dari tiga pendekatan yaitu: (a) implementasi didefenisikan sebagai kegiatan; (b) implementasi berarti upaya yang dilakukan untuk meningkatkan proses interaksi antara guru; dan (c) implementasi adalah entitas yang terpisah dari kurikulum. Saylor dan Alexander dalam Miller (1985:246) mengemukakan gagasan bahwa implementasi kurikulum 
sebagai proses penerapan perencanaan kurikulum dalam bentuk tulisan ke kegiatan belajar yang melibatkan interaksi peserta didik dan guru dalam konteks lingkungan sekolah.

$$
\text { Hasan }
$$

mengemukakan seperti

(2008:11)

dikemukakan oleh Fullan da bahwa penerapan kurikulum adalah upaya yang dilakukan untuk mewujudkan ide-ide, konsep, nilai-nilai dalam bentuk tulis menjadi kenyataan. Pinar (2005:1820) mengemukakan bahwa implementasi kurikulum dapat dipahami sebagai tindakan instrumental dan praktis situasional. Hamalik (2009:237) implementasi merupakan suatu proses penerapan ide, konsep, kebijakan, atau inovasi dalam bentuk tindakan praktis sehingga memberikan dampak, baik berupa perubahan pengetahuan, keterampilan, maupun nilai dan sikap.

Defenisi implemetasi kurikulum di atas maka disimpulkan bahwa implementasi merupakan penerapan ide atau gagasan untuk melaksanakan kebijakan dengan tujuan untuk memberikan hasil yang bersifat praktis.

Mulyasa (2014:181) mendefenisikan bahwa implementasi kurikulum 2013 merupakan aktualisasi kurikulum dalam pembelajaran dan pembentukan kompetensi serta karakter peserta didik. Kurikulum 2013 mengarahkan kepada pendidikan berbasis karakter merupakan tindak lanjut dari Kurikulum Berbasis Kompetesi.

\section{Metode Penelitian}

Jenis penelitian ini merupakan penelitian kualitatif, yaitu penelitian yang dilakukan dengan tujuan utama untuk menggambarkan atau memaparkan suatu obejek yang diteliti yaitu terkait dengan kompetensi pedagogik guru bahasa Indonesia dalam implementasi Kurikulum 2013 di SMA Kabupaten Muna Barat. Hasil penelitian didasarkan hasil observasi, dokumentasi, pengamatan langsung, dan wawancara yang dilakukan pada lokasi penelitian.

Penelitian ini dilaksanakan di Kabupaten Muna Barat, Provinsi Sulawesi Tenggara, sedangkan waktu dilaksanakan penelitian ini adalah Semester Genap Tahun Ajaran 2019/2020.

Metode yang digunakan dalam penelitian ini adalah metode penelitian deskriptif. Metode penelitian deskriptif merupakan sebuah metode yang bertujuan untuk menggambarkan situasi atau fenomena yang dirancang untuk mendapatkan informasi tentang objek yang diamati. Dengan motode tersebut peneliti berusaha menyajikan kenyatankenyataan yang sesungguhnya terjadi, yang ditemukan di lapangan mengenai kompetensi pedagogik guru bahasa Indonesia dalam implementasi Kurikulum 2013 di SMA Kabupaten Muna Barat.

Data dalam penelitian ini adalah informasi tentang kompetensi pedagogik guru bahasa Indonesia dalam implementasi Kurikulum 2013 di SMA Kabupaten Muna Barat yang terdiri atas perencanaan, pelaksanaan, dan penilaian.

Sumber data dalam penelitian ini adalah guru bahasa Indonesia yang mengajar di kelas XI SMA Negeri Kabupaten Muna Barat berjumlah lima orang. Kelima guru ini masing-masing mengajar di lima sekolah yaitu 1 orang guru SMA Negeri 1 Tikep, 1 orang guru SMA Negeri 1 Lawa, 1 orang guru SMA Negeri 1 Barangka, 1 orang guru SMA Negeri 2 Kusambi, 1 orang Guru SMA Negeri 1 Sawerigadi.

Dalam penelitian ini peneliti bertindak sebagai instrumen, sebab peneliti lebih responsif, bersifat adaptif, dan dapat memahami konteks secara keseluruhan. Hal ini sesuai dengan pendapat Sugiono (2012:222) bahwa dalam penelitian kualitatif, yang menjadi 
instrumen atau alat penelitian adalah peneliti itu sendiri. Oleh karena itu, peneliti sebagai instrumen juga harus divalidasi data penelitiannya dan seberapa jauh peneliti kualitatif siap melakukan penelitian yang selanjutnya terjun ke lapangan.

Untuk mendukung instrumen utama di atas, peneliti juga menggunakan panduan instrumen penelitian berupa lembar observasi Alat Penilaian Kompetensi Guru (APKG 1 \& APKG 2) untuk mengetahui kompetensi pedagogik guru bahasa Indonesia dalam implementasi Kurikulum 2013 di SMA Kabupaten Muna Barat.

Teknik pengumpulan data yang digunakan pada penelitian ini adalah sebagai berikut:

\section{Observasi}

Observasi atau pengamatan langsung yaitu melakukan pengamatan sekaligus penilaian kompetensi pedagogik guru bahasa Indonesia dalam implementasi Kurikulum 2013 di SMA Kabupaten Muna Barat dengan menggunakan lembar observasi APKG 1 \& 2 sebagai acuan dalam pennelitian. Teknik pengumpulan data dengan observasi ini digunakan karena penelitian berkenaan dengan perilaku manusia, proses kerja, gejala-gejala alam, dan responden yang diamati tidak terlalu besar. Observasi dalam penelitian ini adalah observasi nonpartisipan, sedangkan bentuk penelitian ini adalah observasi pasif.

2. Wawancara

Data dalam penelitian ini dikumpulkan dengan wawancara terhadap responden. Wawancara merupakan teknik untuk mendapatkan informasi dengan cara bertanya langsung kepada responden. Hal ini penting dilakukan karena peneliti ingin memperoleh informasi yang hanya dapat diperoleh dengan jalan bertanya langsung kepada responden. Pertanyaan yang disampaikan berhubungan dengan implementasi Kurikulum 2013.

3. Dokumentasi

Metode dokumentasi digunakan peneliti untuk memperoleh data terkait dengan perencanaan pembelajaran yakni berupa desain pembelajaran (Silabus dan RPP). Selain itu metode dokumentasi juga digunakan untuk memperkuat data yang diperoleh dari penggunaan metode observasi dan wawancara, dimana hasil penilitian ini akan lebih kredibel dan dapat dipercaya dengan ditunjangnya bukti penelitian berupa dokumentasi gambar atau foto. Serta dapat menggambarkan keadaan yang sebenarnya dari proses belajar mengajar.

Teknik analisis data yang digunakan dalam penelitian ini adalah menggunakan analisis data Model Analisis Interaktif Milles dan Hubberman (dalam Sugiyono, 2012:246) serta menggunakan teknik informant review atau umpan balik dari informan. Berdasarkan jenis penelitian ini yang berbentuk deskriptif, dengan lebih banyak bersifat uraian dari hasil observasi, wawancara, studi dokumentasi, maka data yang telah diperoleh akan dianalisis secara kualitatif serta diuraikan dalam bentuk deskriptif. Adapun teknik analisis data yang digunakan dalam penelitian ini

1. Reduksi Data (Data Reduction)

Redukasi data diartikan sebagai proses pemilihan atau merangkum hal-hal yang pokok, memfokuskan pada hal-hal yang penting, dicari tema dan polanya. Dengan demikian data yang telah direduksi akan memberikan gambaran yang lebih jelas dan mempermudah peneliti untuk melakukan pengumpulan data selanjutnya dan mencarinya bila diperlukan

2. Penyajian Data (Data Display)

Setelah data direduksi, maka langkah selanjutnya adalah mendisplaykan data atau menyajikan 
data. Dalam penyajian data bisa dilakukan dalam bentuk uraian singkat, bagan, hubungan antar kategori, dan sejenisnya. Milles dan Hubberman menyatakan bahwa, yang paling sering digunakan untuk menyajikan data dalam penelitian kualitatif adalah dengan teks yang bersifat naratif. Dengan mendispaykan data, maka akan memudahkan peneliti untuk memahami apa yang terjadi, dan merencanakan kerja selanjutnya berdasarkan apa yang telah dipahami tersebut.

3. Menyimpulkan dan Verifikasi Data

Langkah ketiga dalam teknik analisis data ini adalah, penarikan kesimpulan dan verifikasi. Kesimpulan awal yang dikemukakan masih bersifat sementara dan akan berubah bila tidak ditemukan bukti-bukti yang kuat yang mendukung pada tahap pengumpulan data berikutnya. Tetapi apabila kesimpulan yang dikemukakan pada tahap awal didukung oleh bukti-bukti yang valid dan konsisten saat peneliti kembali ke lapangan mengumpulkan data, maka kesimpulan yang dikemukakan merupakan kesimpulan yang kreadibel.

Keabsahan data yaitu menjamin validitas yang telah dikumpulkan dalam penelitian ini. Teknik yang digunakan dalam penelitian ini adalah teknik informant review atau umpan balik dari informan. Selain itu peneliti menggunakan teknik triangulasi. Triangulasi adalah teknik pemeriksaan keabsahan data yang memanfaatkan sesuatu yang lain diluar data itu untuk keperluan pengecekan atau sebagai pembanding terhadap data itu. Teknik trianulasi yang digunakan pada penelitian ini ada tiga yaitu:

1) Triangulasi dengan sumber, yaitu membandingkan dan mengecek balik derajat kepercayaan suatu informan. Hal yang dapat dicapai dengan jalan (a) membandingkan data hasil pengamatan dengan data wawancara; (b) membandingkan apa yang dikatakan orang didepan umum dengan apa yang dikatakan secara pribadi; (c) membandingkan apa yang dikatakan orang-orang tentang situasi penelitian dengan yang dikatakan sepanjang waktu; (d) membandingka hasil wawancara dengan isi suatu dokumen yang berkaitan.

2) Triangulasi dengan metode, terdapat dua strategi yang harus dilakukan (a) pengecekan derajat penemuan hasil penelitian beberapa teknik pengumpulan data, dan (b) pengecekkan derajat kepercayaan beberapa sumber data dengan metode yang sama.

3) Triangulasi dengan teori, fakta bahwa tidak dapat diperiksa derajat kepercayaan dengan satu teori atau lebih. Hal ini dipertegas bahwa yang demikian dinamakan penjelasan banding, Ghony (2013:322).

Teknik triangulasi yang digunakan dalam penelitian ini ada dua cara yaitu pertama menggunakan triangulasi dengan sumber, yaitu membandingkan perolehan data pada teknik yang berbeda dalam fenomena yang sama. Kedua menggunakan triangulasi dengan metode, yaitu membandingkan perolehan data dari teknik pengumpulan data yang sama dengan sumber yang berbeda.

\section{Hasil Penelitian dan Pembahasan}

Kompetensi pedagogik padasarnya adalah kemampuan guru dalam mengelola pembelajaran kepada peserta didik. Kompetensi pedagogik ini menjadi salah satu jenis kompetensi yang harus dimiliki dan dikuasai guru. Kompetensi guru merupakan kompetensi khusus yang akan membedakan profesi guru dengan profesi lainnya. Penguasaan kompetensi disertai dengan 
profesionalitas akan menentukan tingkat keberhasilan proses dan hasil pelajaran peserta didik. Kompetensi pedagogik ini diperoleh melalui suatu upaya belajar secara terus menerus dan sistematis, baik pada masa pra-jabatan (pendidikan calon guru) maupun selama dalam jabatan, yang didukung oleh bakat, minat dan profesi keguruan lainnya dari hasil pribadi guru yang bersangkutan.

Berdasarkan penelitian yang telah dilaksanakan, dapat diketahui bahwa tingkat kompetensi pedagogik guru dalam implementasi Kurikulum 2013 sebanyak 5 orang menunjukkan kategori baik. Hal ini, menunjukkan bahwa guru kelas XI yang ada di SMA Kabupaten Muna Barat sudah berkualitas dan mampu melaksanakan tugas sesuai dengan profesinya.

Tahap pertama dapat dilihat capaian kompetensi pedagogik guru bahasa Indonesia Kelas XI berdasarkan kemampuan Menyusun Rencana Pelaksanaan Pembelajaran (RPP), menunjukkan bahwa pada tahap perencanaan, guru-guru yang ada di SMA kabupaten Muna Barat, khususnya guru bahasa Indonesia telah menyusun sebuah rancangan pembelajaran sebelum melaksanakan proses belajar mengajar. Demikian juga dengan guru bahasa Indonesia yang mengajar di kelas XI SMA kabupaten Muna Barat, telah mengembangkan dan menyusun Rencana Pelaksanaan Pembelajaran (RPP) sebelum mereka melaksanakan pembelajaran. Hal ini dilaksanakan karena salah satu tugas guru sebelum pelaksanaan proses pembelajaran, terlebih dahulu guru harus mendesain dan menyiapkan perangkat pembelajaran.

Perangkat pembelajaran yang disiapkan guru bahasa Indonesia yang mengajar di keals XI SMA kabupaten Muna Barat, antara lain silabus dan Rencana Pelaksanaan Pembelajaran (RPP). RPP merupakan dokumen kegiatan pembelajaran yang menjadi acuan atau rambu-rambu dalam suatu kegiatan pembelajaran.

Tahap kedua kompetensi pedagogik guru dalam mengimplementasikan Kurikulum 2013, adalah tahap pelaksanaan. Pelaksanaan pembelajaran merupakan suatu proses pengembangan potensi dan pembangunan karakter setiap peserta didik sebagai hasil dari sinergi antara pendidikan yang berlangsung di sekolah, keluarga, dan masyarakat. Proses pembelajaran tersebut dapat memberikan kesempatan kepada peserta didik untuk mengembangkan potensi mereka menjadi kemampuan yang semakin lama semakin meningkat dalam sikap (spiritual dan sosial), pengetahuan, dan keterampilan yang diperlukan oleh peserta didik kelak.

Pelaksanaan pembelajaran bahasa Indonesia di kelas XI kabupaten Muna Barat pada umumnya telah menunjukkan kompetensi karakteristik Kurikulum 2013. Guru bahasa Indoensia yang mengajar di kelas XI telah berusaha untuk menerapkan kurikulum ini sesuai dengan ketentuan yang berlaku, meskipun masih ada guru yang belum maksimal melaksanakannya dalam proses pembelajaran. Hal ini disebabkan karena guru tersebut masih kurang memahami tentang ketentuan-ketentuan yang ada pada kurikulum ini dan masih terbawah pengaruh kurikulum sebelumnya. Tapi pada dasarnya guru bahasa Indonesia yang mengajar di kelas XI tetap berupaya untuk memenulis kompetensi dalam mengimplementasikan Kurikulum 2013 secara maksimal.

Dalam pembelajran dengan karakteristik Kurikulum 2013, guru bahasa Indonesia kelas XI menggunakan pendekatan saintifik atau pendekatan berbasis keilmuan. Pendekatan saintifik yang mereka terapkan dapat menggunakan beberapa model pembelajaran yang disesuaikan dengan 
materi yang akan diajarkan. Modelmodel pembelajaran yang mereka gunakan yaitu, model pembelajaran discovery learning, problem based learning, inquiry learning, dan project based learning.

Berdasarkan hasil pengamatan di kelas pada saat proses belajar-mengajar berlangsung, guru bahasa Indonesia yang mengajar di kelas XI menggunakan modus pembelajaran langsung dan tidak langsung. Pembelajaran langsung yang dilakukan guru tersebut dengan cara mengembangkan pengetahuan, kemampuan berfikir dan keterampilan menggunakan pengetahuan peserta didik melalui interaksi langsung dengan sumber belajar yang dirancang dalam silabus dan RPP. Dalam pembelajaran ini nampak terlihat peserta didik melakukan kegiatan mengamati, menanya, mengumpulkan informasi, kemudian mengolah informasi, dan selanjutkan mengomunikasikan sesuai dengan tahaptahap yang tertuang dalam pendekatan saintifik. Dengan pembelajaran seperti ini dapat menghasilkan pengetahuan dan keterampilan langsung, yang dapat disebut dengan dampak pembelajaran.

Selain pembelajaran langsung yang telah diterapkan, guru bahasa Indonesia kelas XI juga menerapkan pembelajaran tidak langsung yang nampak terjadi selama proses pembelajaran berlangsung. Proses pembelajaran tidak langsung ini berhubungan dengan pengembangan nilai dan sikap yang terkandung dalam KI-1 dan KI-2 yang berupa sikap spiritual dan sikap sosial. Hal ini terlihat ketika proses belajar-mengajar berlangsung guru tetap melaksanakan penilaian proses kepada peserta didik.

Dalam pelaksanaan Kurikulum 2013 SMA kabupaten Muna Barat, dari hasil pengamatan di kelas menunjukkan bahwa guru bahasa Indonesia yang mengajar di kelas XI telah menerapkan langka-langkah pembelajaran saintifik dengan materi/topik proposal. Pada tahap pertama peserta didik secara berkelompok mengamati dengan cara contoh teks proposal yang disediakan oleh guru. Setelah mengamati teks, guru memancing peserta didik untuk bertanya tentang teks yang dibacanya, sehingga nampak terlihat kegiatan tanya-jawab antara peserta didik dengan guru, guru dengan peserta didik, dan antara peserta didik dengan peserta didik. Tahap berikutnya, peserta didik berdiskusi untuk mengumpulkan informasi dari beberapa sumber, seperti dari beberapa buku dan internet tentang materi yang sedang dibahas. Setelah informasi terkumpul, nampak terlihat peserta didik berdiskusi mengolah informasi yang sudah dikumpulkan. Dalam tahap ini nampak terlihat peserta didik mengembangkan interpretasinya, beragumentasi, menyimpulkan menyimpulkan mengenai keterkaitan informasi yang telah mereka dapatkan. Setelah peserta didik mendapatkan satu kesimpulan sebagai hasil diskusi kelompok, maka setiap kelompok mengomunikasikan hasil pekerjaan kepada kelompok lain dengan cara membacakan di depan dan kelompok lain menanggapinya. Dalam proses pembelajaran ini nampak terlihat keaktifan dan antusias peserta didik dalam belajar, meskipun masih terlihat ada yang kurang aktif.

Tahap terakhir kompetensi pedagoik dalam implementasi Kurikulum 2013 adalah tahap penilaian. Penilaian dalam proses pendidikan merupakan komponen yang tidak dapat dipisahkan dari komponen lainnya khususnya pembelajaran. Penilaian adalah suatu bentuk kegiatan guru yang terkait dalam pengambilan keputusan tentang pencapaian kompetensi atau hasil belajar peserta didik yang mengikuti proses pembelajaran tertentu. Untuk itu, 
diperlukan data sebagai informasi yang diandalkan sebagai dasar pengambilan keputusan yang berhubungan dengan sudah atau belum berhasilnya peserta didik dalam mencapai suatu kompetensi. Jadi, penilaian dalam pembelajaran merupakan proses pengumpulan dan pengolahan informasi untuk mengukur pencapaian hasil belajar peserta didik. Penilaian hasil belajar oleh pendidik dilakukan untuk memantau proses, kemajuan belajar, dan perbaikan hasil belajar peserta didik secara berkesinambungan.

Sejalan dengan Peraturan Pemerintah RI Nomor 74 Tahun 2008 tentang Guru pasal 4 menyatakan bahwa kompetensi pedagogik merupakan kemampuan guru dalam pengelolaan pembelajaran peserta didik yang sekurang-kurangnya meliputi: (1) pemahaman wawasan atau landasan kependidikan; (2) pemahaman terhadap peserta didik; (3) pengembangan kurikulum atau silabus; (4) perancangan pembelajaran; (5) pelaksanaan pembelajaran yang mendidik dan dialogis; (6) Pemanfaatan teknologi pembelajaran; (7) evaluasi hasil belajar; dan (8) pengembangan peserta didik untuk mengaktualisasikan berbagai potensi yang dimilikinya.

\section{Kesimpulan dan Saran}

Berdasarkan hasil pengolahan data penelitian dan pembahasan terhadap Kompetensi Pedagogik Guru Bahasa Indonesia dalam Implementasi Kurikum 2013 di SMA Kabupaten Muna Barat, maka dapat disimpulkan sebagai berikut:

1. Kompetensi pedagogik guru bahasa Indonesia Kelas XII berdasarkan kemampuan menyusun Rencana Pelaksanaan Pembelajaran (RPP), Pelasanaan Pembelajaran, dan Pelaksanaan Penilaian Pembelajaran secara keseluruhan berada dalam kategori baik hanya ada beberapa indikator yang masih kurang yaitu indikator kedalaman dan keluasan materi, ketrampilan mengembangkan variasi interaksi, dan ketrampilan menggunakan media pembelajara.

2. Pada aspek komptesi pedagogik guru dalam pelaksanaan pembelajaran, guru SMA Kabupaten Muna Barat khususnya guru bahasa Indonesia yang mengajar di kelas XI secara umum telah menerapkan pendekatan saintifik (pendekatan ilmiah) dalam proses pembelajaran, namun masih ada guru yang terlihat masih kurang dalam menyajikan materi secara sistematis.

Pada aspek kompetensi pedagogik guru dalam penilaian pembelajaran, guru SMA Kabupaten Muna Barat khususnya guru mata pelajaran bahasa Indonesia yang mengajar di kelas XI secara umum telah melakukan penilaian autentik dalam pembelajaran.

Kesimpulan hasil penelitian ini mengasilkan beberapa saran terkait Kompetensi ppimplementasi Kurikulum 2013 sebagai berikut.

1. Pertimbangan untuk meningkatkan pengetahuan dan kompetensi guru perlu adanya kerjasama dari beberapa pihak terkait seperti dinas pendidikan, dengan pelatihan-pelatihan dan pengembangan keprofesionalan berkelanjutan.

2. Diharapkan bagi guru bahasa Indonesia untuk lebih meningkatkan kompetensi pedagogiknya dengan lebih baik lagi, terutama yang masih dalam kategori kurang. Kompetensi pedagogik guru yang sudah baik dan sagat baik atau dikatakan sudah optimal seluruhnya perlu dipertahankan dan ditingkat lagi.

3. Peningkatan pemahaman guru terhadap Kurikulum 2013 melalui kegiatan Kelompok Kerja Guru (KKG) dengan pendampingan dari 
pengawas sekolah dan dinas pendidikan.

4. Dinas pendidikan dan LPMP serta lembaga terkait, hendaknya sering mengadakan pelatihan untuk meningkatkan kompetensi dan kinerja guru dalam implementasi Kurikulum 2013 terkait perencanaan pembelajaran, pelaksanaan pembelajaran, dan penilaian pembelajaran.

\section{Daftar Pustaka}

Achmad, J.A. 2012. Perencanaan Pembelajaran: dari Desain sampai Implementasi. Yogyakarta: PT Pustaka Insan Madani.

Badara, dkk. 2018. Cultural Engineering In Teaching and Learning. (http://www.wseas.us/elibrary/conferences/2015/Salerno/ EDU/EDU-28.pdf)

Firman A.D. 2008. Bunga Rampai Derivasi dalam Bahasa Inggris dan Bahasa Bugis. Kendari: Kantor Bahasa Provinsi Sulawesi Tenggara.

Ghony, M.D. dan Almanshar, F. 2013. Metodologi Penelitian Kualitatif. Yogyakarta: Ar-ruzz Media.

Hamalik, O. 2009. Dasar-dasar Pengembangan Kurikulum. Bandung: Remaja Rosdakarya.

Hasan, S.H. 2008. Evaluasi Kurikulum. Bandung: PT. Remaja Rosda Karya.

Hernawan, A.H. 2013. Pengembangan Kurikulum dan pembelajaran di $S D$. Tangeran Selatan: Universitas Terbuka.

Kemdikbud. 2016. Panduan Penilaian untuk Sekolah Dasar. Jakarta: Dirjen Dikdasmen

Kurniasih, I. \& Sani, B. 2016. Ragam Pengembangan - Model Pembelajaran - Untuk Peningkatan Professionalitas Guru. Yogyakarta: Kata Pena.
Miller. J.P \& Seller, W. 1985. Curriculum, Perspective, and Practise. London: Longman

Mulyasa. E.2013. Standar Kompetensi dan Sertifikasi Guru. Bandung: Remaja Rosdakarya.

Peraturan Pemerintah Republik Indonesia Nomor 74 tahun 2008 tentang Guru.

Permendikbud Nomor 20 Tahun 2016 tentang Standar Kompetensi Lulusan Pendidikan Dasar dan Menengah.

Pinar, W.F \& Irwin, R.L. 2005. Curriculum ina New Key: The Collected Works of Ted T. Aoki. NJ: Lawrence Erbaum Associates.

Sagala, Syaiful. 2009. Kemampuan Profesional Guru dan Tenaga Kependidikan. Bandung: Alfabeta.

Sugiyono. 2012. Metode Penelitian Kuantitatif, Kualitatif, dan R\&D. Bandung: Alfabeta.

Undang-Undang Nomor 14 Tahun 2005 tentang Guru dan Dosen. 